BHI-01022

Rev. 0

\title{
Sampling and Analysis Instruction for the 120-F-1 Glass Dump Site
}

Author

T. M. Brown

Date Published

March 1998

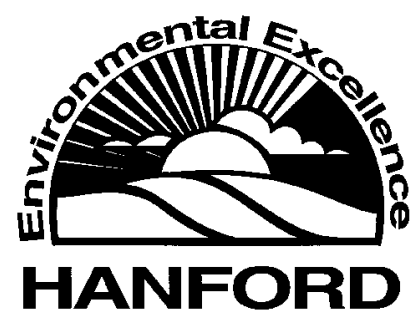

Prepared for the U.S. Department of Energy Office of Environmental Restoration and Waste Management

Bechtel Hanford, Inc.

Richland, Washington 
TRADEMARK DISCLAIMER

Reference herein to any specific commercial product, process, or service by trade name, trademark, manufacturer, or otherwise, does not necessarily constitute or imply its endorsement,

recommendation, or favoring by the United States Government or any agency thereof or its contractors or subcontractors.

This report has been reproduced from the best available copy. Available in paper copy and microfiche.

Available to the U.S. Department of Energy

and its contractors from

Office of Scientific and Technical Information

P.O. Box 62

Oak Ridge, TN 37831

(615) $576-8401$

Available to the public from the U.S. Department of Commerce

National Technical Information Service

5285 Port Royal Road

Springfield, VA 22161

(703) 487-4650

Printed in the United States of America

DISCLM-5.CHP (8-91) 
BHI-01022

Rev. 0

\section{CONTENTS}

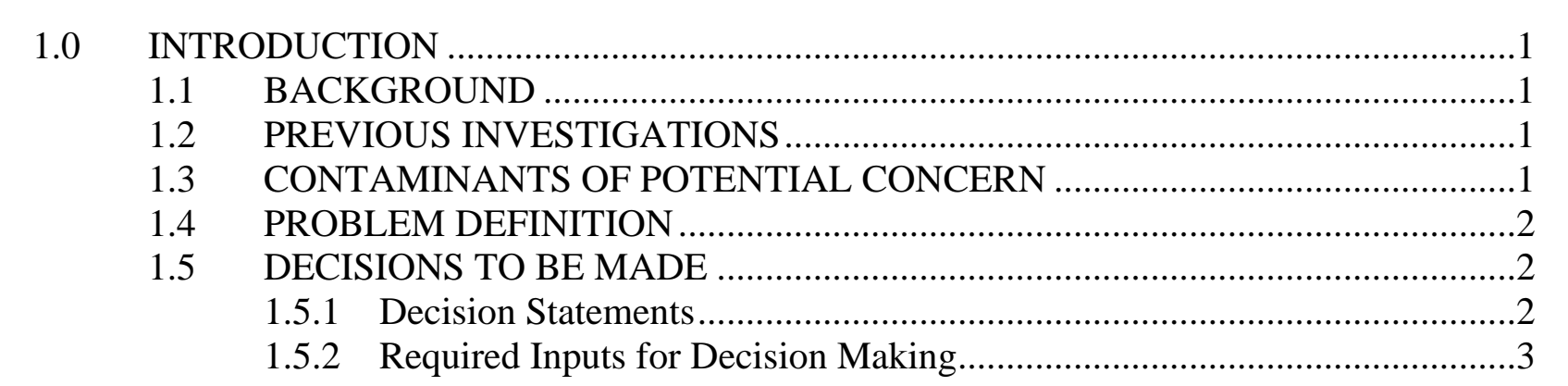

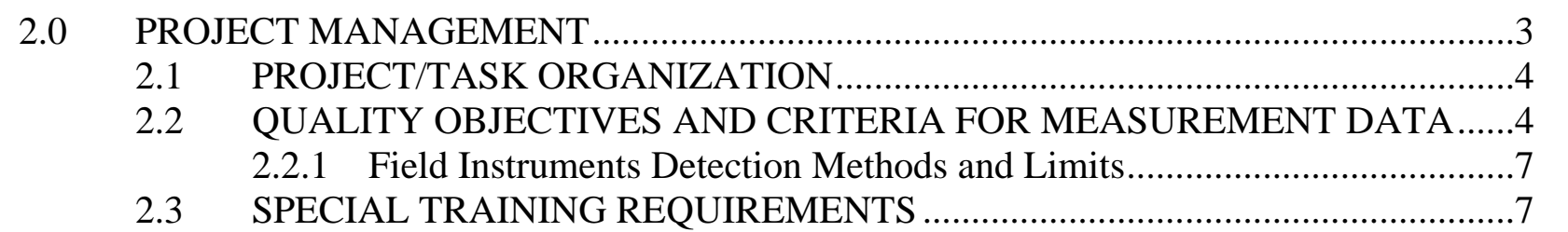

\begin{tabular}{|c|c|}
\hline & UREMENT/DATA ACQUISITION \\
\hline 3.1 & SAMPLING PROCESS DESIGN \\
\hline 3.2 & SAMPLING METHODS REQUIREMENTS \\
\hline 3.3 & SAMPLE HANDLING, SHIPPING, AND CUSTODY REQUIREMENTS ..........8 \\
\hline 3.4 & SAMPLE PRESERVATION, CONTAINERS, AND HOLDING TIMES.............8 \\
\hline 3.5 & QUALITY CONTROL REQUIREMENTS. \\
\hline 3.6 & INSTRUMENT CALIBRATION AND MAINTENANCE.. \\
\hline 3.7 & FIELD DOCUMENTATION ... \\
\hline
\end{tabular}

\begin{tabular}{|c|c|}
\hline 4.0 & 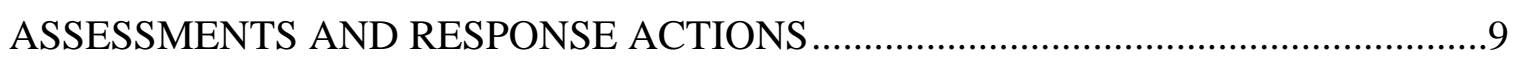 \\
\hline 5.0 & DATA VERIFICATION AND VALIDATION REQUIREMENTS ………............. \\
\hline 6.0 & 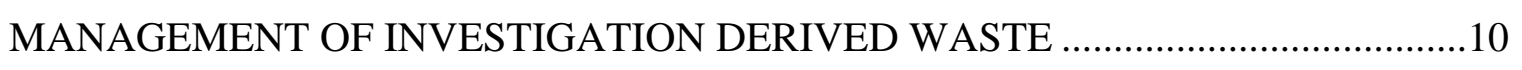 \\
\hline 7.0 & HEALTH AND SAFETY. \\
\hline 8.0 & $\ldots$ \\
\hline
\end{tabular}

\section{FIGURE}

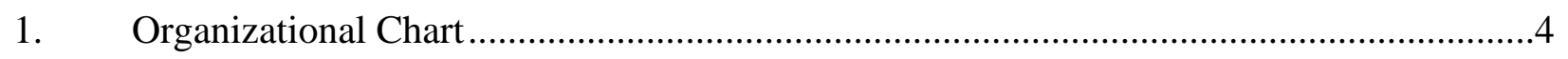


BHI-01022

Rev. 0

\section{CONTENTS (cont.)}

\section{TABLES}

1. Table Summarizing Data Quality Requirements for Solid Media..........................................5

2. Table Summarizing Data Quality Requirements for Liquid Media......................................6 
BHI-01022

Rev. 0

\section{ACRONYMS AND ABBREVIATIONS}

$\begin{array}{ll}\mathrm{Ag} & \text { silver } \\ \mathrm{Am} & \text { americium } \\ \mathrm{As} & \text { arsenic } \\ \mathrm{Ba} & \text { barium } \\ \mathrm{BHI} & \text { Bechtel Hanford, Inc. } \\ \mathrm{Cd} & \text { cadmium } \\ \mathrm{Co} & \text { cobalt } \\ \mathrm{COPC} & \text { contaminants of potential concern } \\ \mathrm{Cr} & \text { chromium } \\ \mathrm{Cs} & \text { cesium } \\ \mathrm{dpm} & \text { disintegration per minute } \\ \mathrm{ERC} & \text { Environmental Restoration Contractor } \\ \mathrm{Eu} & \text { europium } \\ \mathrm{Hg} & \text { mercury } \\ \mathrm{Pb} & \text { lead } \\ \mathrm{PCB} & \text { polychlorinated biphenyl } \\ \mathrm{Pu} & \text { plutonium } \\ \mathrm{QC} & \text { quality control } \\ \mathrm{SAI} & \text { sampling and analysis instruction } \\ \mathrm{Se} & \text { selenium } \\ \mathrm{Sr} & \text { strontium } \\ \mathrm{TCLP} & \text { toxic characteristic leaching procedure } \\ \mathrm{TOC} & \text { total organic carbon } \\ \mathrm{U} & \text { uranium }\end{array}$


BHI-01022

Rev. 0

\section{Metric Conversion Chart}

The following conversion chart is provided to the reader as a tool to aid in conversion.

\begin{tabular}{|c|c|c|c|c|c|}
\hline \multicolumn{3}{|c|}{ Into Metric Units } & \multicolumn{3}{|c|}{ Out of Metric Units } \\
\hline If You Know & Multiply By & To Get & If You Know & Multiply By & To Get \\
\hline \multicolumn{3}{|l|}{ Length } & \multicolumn{3}{|l|}{ Length } \\
\hline inches & 25.4 & Millimeters & millimeters & 0.039 & inches \\
\hline inches & 2.54 & Centimeters & centimeters & 0.394 & inches \\
\hline feet & 0.305 & Meters & meters & 3.281 & feet \\
\hline yards & 0.914 & Meters & meters & 1.094 & yards \\
\hline miles & 1.609 & Kilometers & kilometers & 0.621 & miles \\
\hline \multicolumn{3}{|l|}{ Area } & \multicolumn{3}{|l|}{ Area } \\
\hline sq. inches & 6.452 & sq. centimeters & sq. centimeters & 0.155 & sq. inches \\
\hline sq. feet & 0.093 & sq. meters & sq. meters & 10.76 & sq. feet \\
\hline sq. yards & 0.0836 & sq. meters & sq. meters & 1.196 & sq. yards \\
\hline sq. miles & 2.6 & sq. kilometers & sq. kilometers & 0.4 & sq. miles \\
\hline acres & 0.405 & hectares & hectares & 2.47 & acres \\
\hline \multicolumn{3}{|c|}{ Mass (weight) } & \multicolumn{3}{|l|}{ Mass (weight) } \\
\hline Ounces & 28.35 & grams & grams & 0.035 & ounces \\
\hline Pounds & 0.454 & kilograms & kilograms & 2.205 & pounds \\
\hline Ton & 0.907 & Metric ton & metric ton & 1.102 & ton \\
\hline \multicolumn{3}{|l|}{ Volume } & \multicolumn{3}{|l|}{ Volume } \\
\hline teaspoons & 5 & Milliliters & milliliters & 0.033 & fluid ounces \\
\hline tablespoons & 15 & Milliliters & & & \\
\hline fluid ounces & 30 & Milliliters & & & \\
\hline cups & 0.24 & Liters & & & \\
\hline pints & 0.47 & Liters & liters & 2.1 & pints \\
\hline quarts & 0.95 & Liters & liters & 1.057 & quarts \\
\hline gallons & 3.8 & Liters & liters & 0.264 & gallons \\
\hline cubic feet & 0.028 & cubic meters & cubic meters & 35.315 & cubic feet \\
\hline cubic yards & 0.765 & Cubic meters & cubic meters & 1.308 & cubic yards \\
\hline \multicolumn{3}{|c|}{ Temperature } & \multicolumn{3}{|l|}{ Temperature } \\
\hline Fahrenheit & $\begin{array}{l}\text { subtract } 32 \text {, } \\
\text { then multiply } \\
\text { by } 5 / 9\end{array}$ & Celsius & Celsius & $\begin{array}{l}\text { Multiply by } \\
9 / 5, \text { then } \\
\text { add } 32\end{array}$ & Fahrenheit \\
\hline \multicolumn{3}{|c|}{ Radioactivity } & \multirow{2}{*}{\multicolumn{3}{|c|}{$\begin{array}{l}\text { Radioactivity } \\
\text { becquerel }\end{array}$}} \\
\hline curies & $3.7 \times 10^{10}$ & Becquerel & & & \\
\hline
\end{tabular}


BHI-01022

Rev. 0

\subsection{INTRODUCTION}

This sampling and analysis instruction (SAI) has been prepared to clearly define the sampling and analysis activities to be performed to develop the basis for surveillance and maintenance (S\&M) of the 120-F-1 Glass Dumpsite. The purpose of this investigation is to augment historical information and obtain data to establish a technical basis for S\&M at the site.

\subsection{BACKGROUND}

The Glass Dumpsite is an inactive trench that runs east to west. The site is covered with approximately $0.61 \mathrm{~m} \mathrm{(} 2 \mathrm{ft}$ ) of fluorescent tubes; incandescent light bulbs; instrument vacuum tubes; and small AAA, C, D cell batteries. The site also contains an assortment of chemical bottles, both large and small. The potential source of these chemical bottles is 108-F Laboratory. The site is located $275 \mathrm{~m}$ south of 128-F-1, 100-F burning pit and $650 \mathrm{~m}$ south-southeast of Building 105-F. Earth from the excavation has been mounded at the west end of the trench. The

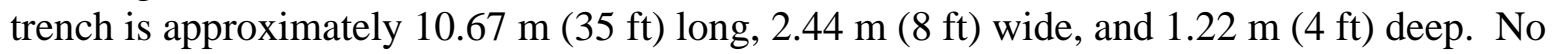
back filling appears to have occurred.

\subsection{PREVIOUS INVESTIGATIONS}

There were no previous investigations identified. Although it has been purported that a radiation survey was performed several years ago, no results are available. Concurrent with the preparation of this report, radiation surveys were conducted and have identified no detectable radiation. However, this radiation survey did not provide enough information to remove radiation protection requirements for field activity. Industrial hygiene technicians performed a background detection survey for total organic vapors, mercury vapors, and explosive gases. Mercury vapors were detected higher than background levels near the openings of broken fluorescent light tubes. No vapors were detected near the breathing zone.

\subsection{CONTAMINANTS OF POTENTIAL CONCERN}

The site is situated in the 100-F Area and the 108-F Laboratory is a potential source of the contents of the site. Therefore, the following list of contaminants of potential concern (COPC) will be utilized based on 108-F potential contaminants.

Radionuclide COPCs:

$\begin{array}{lllllll}\text { Am-241 } & \text { Co-60 } & \text { Cs-137 } & \text { Eu-152 } & \text { Eu-154 } & \text { Sr-90 } & \text { U-234 } \\ \text { U-235 } & \text { U-238 } & \text { Pu-238 } & \text { Pu-239/240 } & & \end{array}$

Metals:

$\begin{array}{llllllll}\text { As } & \mathrm{Ba} & \mathrm{Cd} & \mathrm{Cr} & \mathrm{Hg} & \mathrm{Pb} & \mathrm{Se} & \mathrm{Ag}\end{array}$


BHI-01022

Rev. 0

Others:

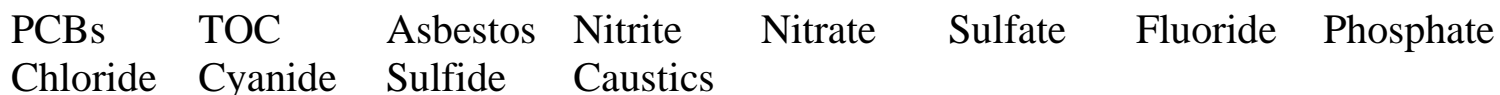

\subsection{PROBLEM DEFINITION}

The problem is that there is not enough information to provide a technical basis for S\&M. Some information was obtained from the Waste Information Data System and historical site review regarding the debris that was placed in the site. The primary goals of this SAI are to identify surface chemical and radiation hazards that pose an industrial health and safety threat to the field personnel associated with the Glass Dumpsite. The information acquired is not intended for waste designation or site closure purposes.

\subsection{DECISIONS TO BE MADE}

The following section presents all of the decisions that need to be made to resolve the problem identified in Section 1.4, along with the inputs needed to resolve each decision.

\subsubsection{Decision Statements}

1. Determine whether the residual white powder in the jar located on the south side of the dumpsite contains hazardous material. If the material is hazardous, this information can be passed on to the Remedial Action group. The consequence of a wrong decision is that the material is hazardous and the Remedial Action group is not notified. This information will be incidental since the Remedial Action group will fully characterize the dumpsite prior to remediation. Final remediation activities will not be planned solely on information obtained from the implementation of this SAI.

2. Determine whether residual radioactive contamination is present at or near the surface from previous uses. If there is radioactive contamination at or near the surface, this information can be passed on to the Remedial Action group. The consequence of a wrong decision is that radioactive contamination is present and the Remedial Action group is not notified. The lack of this information will be incidental since the Remedial Action group will fully characterize the dumpsite prior to remediation. Final remediation activities will not be planned solely on information obtained from the implementation of this SAI.

3. Determine whether residual chemical contamination is present at or near the surface from previous uses. If there is chemical contamination at or near the surface, this information can be passed on to the Remedial Action group. The consequence of a wrong decision is that chemical contamination is present and the Remedial Action group is not notified. 
BHI-01022

Rev. 0

The lack of this information will be incidental since the Remedial Action group will fully characterize the dumpsite prior to remediation. Final remediation activities will not be planned solely on information obtained from the implementation of this SAI.

\subsubsection{Required Inputs for Decision Making}

Inputs required for Decision 1:

To determine whether the residual white powder in the jar located on the south side of the dumpsite contains hazardous material, it shall be analyzed for COPCs according to the priorities identified in Tables 1 and 2.

Inputs required for Decision 2:

To determine whether radioactive contamination is present at or near the surface from previous uses, a direct survey of as much area as possible and at least 60 technical smear surveys shall be analyzed. This will produce a smearable limit of less than $100 \mathrm{dpm}$ cesium-137 equivalent beta and less than $10 \mathrm{dpm}$ plutonium-239 equivalent alpha.

If no contamination is detected with field instruments, radiological coverage requirements will not be applicable, but will be provided as a courtesy for the remainder of the assessment.

If detectable contamination is found above the 95 percent upper confidence level minimum detectable activity of the instruments, samples from the affected area/item shall be analyzed according to the priorities identified in Table 2 .

Inputs required for Decision 3:

To determine whether potential chemical contamination is present at or near the surface from previous uses, the area will be surveyed visually for suspicious conditions (discoloration, etc.). Samples will be taken from suspicious areas discovered in the visual survey, if necessary.

\subsection{PROJECT MANAGEMENT}

The following section identifies the individuals or organizations participating in the project and discusses specific roles and responsibilities of the individuals/organizations. This section also discusses the quality objectives for measurement data, and discusses the special training requirements for the staff performing the work. 
BHI-01022

Rev. 0

\section{$2.1 \quad$ PROJECT/TASK ORGANIZATION}

The task shall be managed through the Surveillance/Maintenance and Transition Project (see Figure 1 for organizational chart) and has been assigned to the Inactive Facilities Surveillance and Maintenance/Radiation Area Remedial Action Task Lead. The Environmental Restoration Contractor (ERC) Field Support Group shall provide assistance in site preparation, assist in collecting samples, and overall supervision of the field activity. The Sample and Data Management Group arrange for analytical services. The ERC Safety and Health Group shall provide radiological control, industrial safety and health support as required, while the ERC Assessment and Environmental Compliance Group shall ensure that environmental activities are performed in a responsible manner.

Figure 1. Organizational Chart

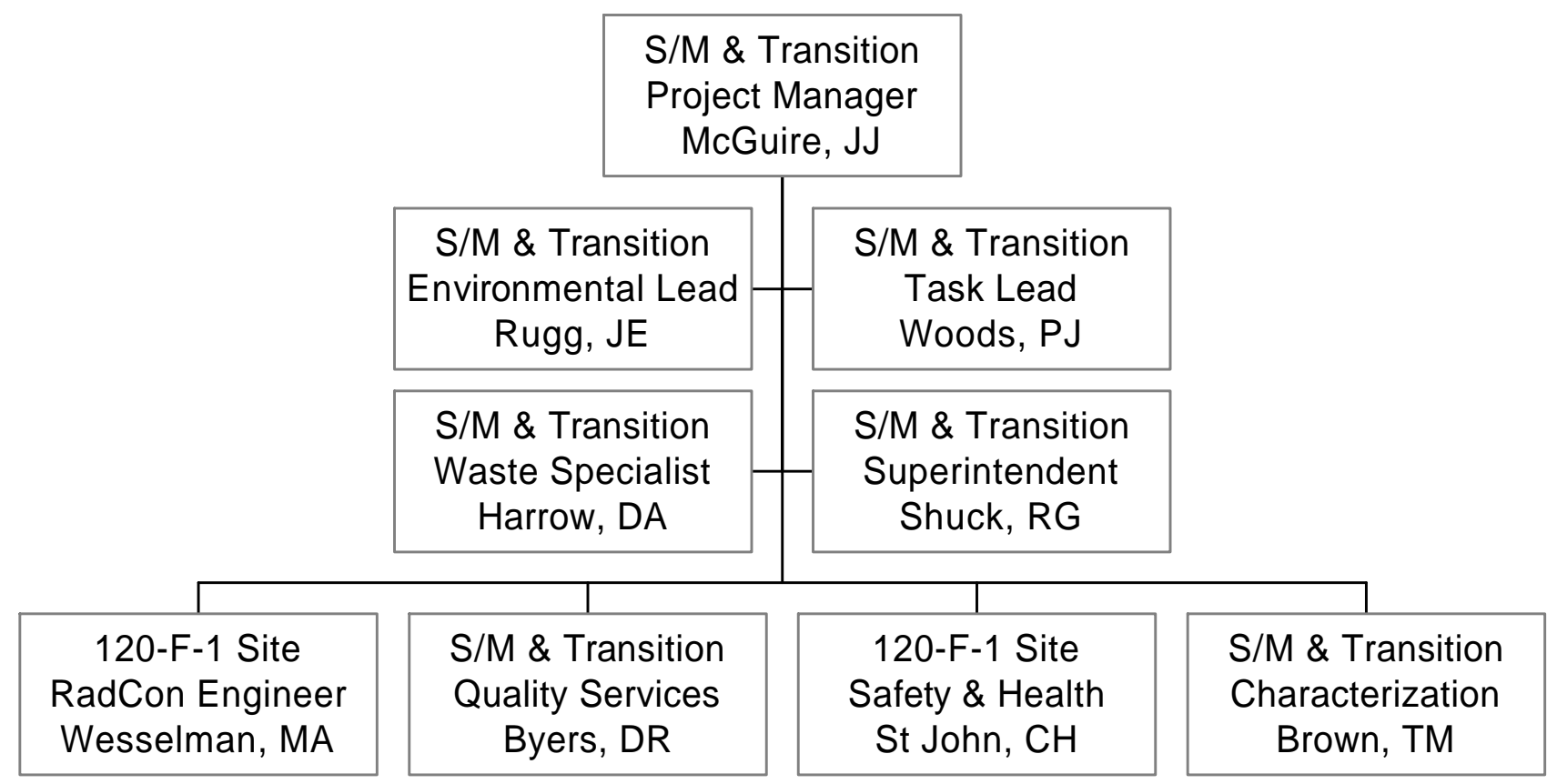

\subsection{QUALITY OBJECTIVES AND CRITERIA FOR MEASUREMENT DATA}

The required detection limits and precision and accuracy requirements for each of the analyses to be performed are summarized in Tables 1 and 2 . The tables are in sample analysis priority order. 
BHI-01022

Rev. 0

Table 1. Table Summarizing Data Quality Requirements for Solid Media.

\begin{tabular}{|c|c|c|c|c|c|c|}
\hline Media & $\begin{array}{c}\text { Analytical } \\
\text { Method }\end{array}$ & $\begin{array}{l}\text { Analytical } \\
\text { Parameter }\end{array}$ & $\begin{array}{c}\text { Regulatory } \\
\text { Limit }\end{array}$ & $\begin{array}{c}\text { Detection } \\
\text { Limit }^{1} \\
\text { pCi/g or } \\
\text { mg/kg }\end{array}$ & Precision & Accuracy \\
\hline Solids & Microscopy & Asbestos & N/A & $1 \%$ & $+/-30 \%$ & $+/-30 \%$ \\
\hline Solids & Electrode/paper & Caustics & N/A & $\begin{array}{ll}0.1 & 0.1 \\
\end{array}$ & $+/-30 \%$ & $+/-30 \%$ \\
\hline Solids & Ion Chrom. - EPA300.0 & Nitrate & N/A & 0.15 & $+/-30 \%$ & $+/-30 \%$ \\
\hline Solids & Ion Chrom. - EPA300.0 & Nitrite & N/A & 0.15 & $+/-30 \%$ & $+/-30 \%$ \\
\hline Solids & Ion Chrom. - EPA300.0 & Sulfate & N/A & 210 & $+/-30 \%$ & $+/-30 \%$ \\
\hline Solids & Ion Chrom. - EPA300.0 & Fluoride & N/A & 0.21 & $+/-30 \%$ & $+/-30 \%$ \\
\hline Solids & Ion Chrom. - EPA300.0 & Phosphate & N/A & 210 & $+/-30 \%$ & $+/-30 \%$ \\
\hline Solids & Ion Chrom. - EPA300.0 & Chloride & N/A & $2 \quad 10$ & $+/-30 \%$ & $+/-30 \%$ \\
\hline Solids & SW846-1311/6010 & Arsenic & N/A & Extract $^{2} \gg \gg$ & $+/-30 \%$ & $+/-30 \%$ \\
\hline Solids & SW846-1311/6010 & Barium & N/A & Extract $^{2} \gg \gg$ & $+/-30 \%$ & $+/-30 \%$ \\
\hline Solids & SW846-1311/6010 & Cadmium & N/A & Extract $^{2} \gg>>$ & $+/-30 \%$ & $+/-30 \%$ \\
\hline Solids & SW846-1311/6010 & Chromium & N/A & Extract $^{2} \gg \gg>$ & $+/-30 \%$ & $+/-30 \%$ \\
\hline Solids & SW846-1311/6010 & Lead & N/A & Extract $^{2} \gg \gg$ & $+/-30 \%$ & $+/-30 \%$ \\
\hline Solids & SW846-1311/6010 & Selenium & N/A & Extract $^{2} \gg \gg$ & $+/-30 \%$ & $+/-30 \%$ \\
\hline Solids & SW846-1311/6010 & Silver & N/A & Extract $^{2} \gg \gg$ & $+/-30 \%$ & $+/-30 \%$ \\
\hline Solids & SW846-1311/6010 & Mercury & N/A & Extract $^{2} \gg \gg$ & $+/-30 \%$ & $+/-30 \%$ \\
\hline Solids & SW-846-9010/9012 & Cynaide & N/A & .53 & $+/-30 \%$ & $+/-30 \%$ \\
\hline Solids & Sw-846-9030 & Sulfide & N/A & $4 \quad 10$ & $+/-30 \%$ & $+/-30 \%$ \\
\hline Solids & GC/MS SW-846 - 8270 & Semi-Volatile Organics & N/A & $0.5 \quad 0.5$ & $+/-30 \%$ & $+/-30 \%$ \\
\hline Solids & GC/MS SW-846 - 8260 & Volatile Organics & N/A & $.002 \quad .002$ & $+/-30 \%$ & $+/-30 \%$ \\
\hline Solids & GC SW-846 - 8080 & PCBs (if soils) & N/A & $0.05 \quad 10$ & $+/-30 \%$ & $+/-30 \%$ \\
\hline Solids & Gamma Energy Analysis & Co-60 & N/A & 0.11 & $+/-3 \sigma$ & $+/-3 \sigma$ \\
\hline Solids & Gamma Energy Analysis & Cs-137 & N/A & $0.1 \quad 1$ & $+/-3 \sigma$ & $+/-3 \sigma$ \\
\hline Solids & Gamma Energy Analysis & Eu-152 & N/A & 0.11 & $+/-3 \sigma$ & $+/-3 \sigma$ \\
\hline Solids & Gamma Energy Analysis & Eu-154 & N/A & $0.1 \quad 1$ & $+/-3 \sigma$ & $+/-3 \sigma$ \\
\hline Solids & Proportional Counting & Gross Alpha & N/A & $10 \quad 25$ & $+/-30 \%$ & $+/-30 \%$ \\
\hline Solids & Proportional Counting & Gross Beta & N/A & $15 \quad 30$ & $+/-30 \%$ & $+/-30 \%$ \\
\hline Solids & Beta Counting & Sr-90 & N/A & 15 & $+/-30 \%$ & $+/-30 \%$ \\
\hline Solids & Alpha Energy Analysis & $\mathrm{Pu}-238, \mathrm{Pu}-239 / 240$ & N/A & 120 & $+/-30 \%$ & $+/-30 \%$ \\
\hline Solids & Alpha Energy Analysis & Am-241 & N/A & 120 & $+/-30 \%$ & $+/-30 \%$ \\
\hline Solids & Alpha Energy Analysis & U-234, U-235, U-238 & N/A & 120 & $+/-30 \%$ & $+/-30 \%$ \\
\hline
\end{tabular}

${ }^{1}$ First value is for "Full Protocol"; second value is for Rapid Turn around or Reduced Volume analysis. Full Protocol detection limits require larger volume shown. Detection limits are based on optimal conditions. Sample specific matrix effects or interference may raise the values shown ${ }^{2}$ TCLP values are reported as liquid extract concentrations for solid samples and bulk liquid concentrations for liquid samples. 
BHI-01022

Rev. 0

Table 2. Table Summarizing Data Quality Requirements for Liquid Media.

\begin{tabular}{|c|c|c|c|c|c|c|}
\hline Media & $\begin{array}{c}\text { Analytical } \\
\text { Method }\end{array}$ & $\begin{array}{l}\text { Analytical } \\
\text { Parameter }\end{array}$ & $\begin{array}{c}\text { Regulatory } \\
\text { Limit }\end{array}$ & $\begin{array}{c}\text { Detection } \\
\text { Limit }^{1} \\
\text { pCi/L or } \\
\text { ug/L }\end{array}$ & Precision & Accuracy \\
\hline Liquid & Microscopy & Asbestos & N/A & $1 \%$ & $+/-30 \%$ & $+/-30 \%$ \\
\hline Liquid & Electrode/paper & Caustics & N/A & $\begin{array}{ll}0.1 & 0.1\end{array}$ & $+/-30 \%$ & $+/-30 \%$ \\
\hline Liquid & Ion Chrom. - EPA300.0 & Nitrate & N/A & 0.15 & $+/-30 \%$ & $+/-30 \%$ \\
\hline Liquid & Ion Chrom. - EPA300.0 & Nitrite & N/A & 0.15 & $+/-30 \%$ & $+/-30 \%$ \\
\hline Liquid & Ion Chrom. - EPA300.0 & Sulfate & N/A & 210 & $+/-30 \%$ & $+/-30 \%$ \\
\hline Liquid & Ion Chrom. - EPA300.0 & Fluoride & N/A & 0.21 & $+/-30 \%$ & $+/-30 \%$ \\
\hline Liquid & Ion Chrom. - EPA300.0 & Phosphate & N/A & 210 & $+/-30 \%$ & $+/-30 \%$ \\
\hline Liquid & Ion Chrom. - EPA300.0 & Chloride & N/A & 210 & $+/-30 \%$ & $+/-30 \%$ \\
\hline Liquid & SW846 - 1311/6010 & Arsenic & N/A & Extract $^{2} \gg \gg>$ & $+/-30 \%$ & $+/-30 \%$ \\
\hline Liquid & SW846 - 1311/6010 & Barium & N/A & Extract $^{2} \gg>>$ & $+/-30 \%$ & $+/-30 \%$ \\
\hline Liquid & SW846 - 1311/6010 & Cadmium & N/A & Extract $^{2} \gg \gg>$ & $+/-30 \%$ & $+/-30 \%$ \\
\hline Liquid & SW846 - 1311/6010 & Chromium & N/A & Extract $^{2} \gg>>$ & $+/-30 \%$ & $+/-30 \%$ \\
\hline Liquid & SW846 - 1311/6010 & Lead & N/A & Extract $^{2} \gg \gg$ & $+/-30 \%$ & $+/-30 \%$ \\
\hline Liquid & SW846 - 1311/6010 & Selenium & N/A & Extract $^{2} \gg \gg>$ & $+/-30 \%$ & $+/-30 \%$ \\
\hline Liquid & SW846 - 1311/6010 & Silver & N/A & Extract $^{2} \gg>>$ & $+/-30 \%$ & $+/-30 \%$ \\
\hline Liquid & SW846 - 1311/6010 & Mercury & N/A & Extract $^{2} \gg \gg>$ & $+/-30 \%$ & $+/-30 \%$ \\
\hline Liquid & SW-846 - 9010/9012 & Cynaide & N/A & .53 & $+/-30 \%$ & $+/-30 \%$ \\
\hline Liquid & Sw-846 - 9030 & Sulfide & N/A & $4 \quad 10$ & $+/-30 \%$ & $+/-30 \%$ \\
\hline Liquid & GC/MS SW-846 - 8270 & Semi-Volatile Organics & N/A & $0.5 \quad 0.5$ & $+/-30 \%$ & $+/-30 \%$ \\
\hline Liquid & GC/MS SW-846 - 8260 & Volatile Organics & N/A & .002 .002 & $+/-30 \%$ & $+/-30 \%$ \\
\hline Liquid & GC SW-846 - 8080 & PCBs (if oily) & N/A & 0.0510 & $+/-30 \%$ & $+/-30 \%$ \\
\hline Liquid & Gamma Energy Analysis & Co-60 & N/A & 0.11 & $+/-3 \sigma$ & $+/-3 \sigma$ \\
\hline Liquid & Gamma Energy Analysis & Cs-137 & N/A & 0.11 & $+/-3 \sigma$ & $+/-3 \sigma$ \\
\hline Liquid & Gamma Energy Analysis & Eu-152 & N/A & $0.1 \quad 1$ & $+/-3 \sigma$ & $+/-3 \sigma$ \\
\hline Liquid & Gamma Energy Analysis & Eu-154 & N/A & $0.1 \quad 1$ & $+/-3 \sigma$ & $+/-3 \sigma$ \\
\hline Liquid & Proportional Counting & Gross Alpha & N/A & $10 \quad 25$ & $+/-30 \%$ & $+/-30 \%$ \\
\hline Liquid & Proportional Counting & Gross Beta & N/A & $15 \quad 30$ & $+/-30 \%$ & $+/-30 \%$ \\
\hline Liquid & Beta Counting & Sr-90 & N/A & 15 & $+/-30 \%$ & $+/-30 \%$ \\
\hline Liquid & Alpha Energy Analysis & $\mathrm{Pu}-238, \mathrm{Pu}-239 / 240$ & N/A & $\begin{array}{ll}120 \\
\end{array}$ & $+/-30 \%$ & $+/-30 \%$ \\
\hline Liquid & Alpha Energy Analysis & Am-241 & N/A & 120 & $+/-30 \%$ & $+/-30 \%$ \\
\hline Liquid & Alpha Energy Analysis & U-234, U-235, U-238 & N/A & 120 & $+/-30 \%$ & $+/-30 \%$ \\
\hline
\end{tabular}

${ }^{1}$ First value is for "Full Protocol"; second value is for Rapid Turn around or Reduced Volume analysis. Full Protocol detection limits require larger volume shown. Detection limits are based on optimal conditions. Sample specific matrix effects or interference may raise the values shown. ${ }^{2}$ TCLP values are reported as liquid extract concentrations for solid samples and bulk liquid concentrations for liquid samples. 
BHI-01022

Rev. 0

\subsubsection{Field Instruments Detection Methods and Limits}

The radiation detection methods and limits will be in accordance with the ERC procedures. The instruments used shall be capable of detecting down to $3000 \mathrm{dpm} / 100 \mathrm{~cm}^{2}$ total activity while scanning at four inches per second, $1000 \mathrm{dpm} / \mathrm{smear}$ beta and can detect $100 \mathrm{dpm} / 100 \mathrm{~cm}^{2}$ alpha on a static count.

The instruments used in detecting total organic vapors shall have 1 part per million above background as a minimum detectable signal. The instruments used in detecting mercury vapor shall have $0.003 \mathrm{mg} / \mathrm{m}^{3}$ above background. The instruments used in detecting explosive gases shall have capability to detect 1 percent lower explosive limit (15 to 21 percent oxygen environment).

\subsection{SPECIAL TRAINING REQUIREMENTS}

Training or certification requirements needed by personnel are described in BHI-HR-02, ERC Training Procedures, and BHI-QA-03, ERC Quality Assurance, Plan Numbers 5.1, Field Sampling Quality Assurance Program Plan," and 5.2, "Onsite Measurements Quality Assurance Program Plan." Decontamination and Decommissioning workers, Radiological Control Technicians, Samplers, and other field personnel shall have completed before starting work any other training as defined by the work package including a current physical.

\subsection{MEASUREMENT/DATA ACQUISITION}

The following section presents the sampling process design, along with the requirements for sampling methods, sample handling, custody, preservation, containers, and holding times. This section also addresses the requirements for field and laboratory quality control (QC), instrument calibration and maintenance, and field documentation.

\subsection{SAMPLING PROCESS DESIGN}

The Analytical Field Services organization needs to collect samples at the 120-F-1 Glass Dumpsite. Based on field observations, there is very little sample media present at the site. Follow all protocols identified in the procedures. Collect the container of powder/solid on the south edge of the site for sample analysis. Exercising professional judgement, use an extension devise and slightly move surface items and containers. Collect any potential sample media for sample analysis. Detailed field documentation is absolutely necessary for this activity and will be recorded in the Analytical Field Services Sample log. 
BHI-01022

Rev. 0

\subsection{SAMPLING METHODS REQUIREMENTS}

The procedures to be implemented in the field should be consistent with those outlined in BHI-EE-01, Environmental Investigation Procedures, including the following:

$\begin{array}{clc}\text { Procedure \# } & \text { Procedure Title } & \text { Revision \# } \\ 1.5 & \text { Field Logbooks } & 2 \\ 2.0 & \text { Sample Event Coordination } & 1 \\ 2.1 & \text { Sampling Documentation Processing } & 1 \\ 2.2 & \text { Data Package Receipt and Control } & 1 \\ 2.7 & \text { Sample Disposition Record } & 1 \\ 3.0 & \text { Chain of Custody } & 2 \\ 3.1 & \text { Sample Packaging and Shipping } & 1 \\ 4.0 & \text { REVISION ORDER } & \text { A } \\ & \text { Soil and Sediment Sampling } & 2 \\ 4.2 & \text { Sample Storage and Shipping Facility } & 2 \\ 4.4 & \text { Container Sampling } & 0\end{array}$

\subsection{SAMPLE HANDLING, SHIPPING, AND CUSTODY REQUIREMENTS}

All sample handling, shipping, and custody should be performed in accordance with BHI-EE-01 procedures identified in Section 3.2 above.

\subsection{SAMPLE PRESERVATION, CONTAINERS, AND HOLDING TIMES}

The sample preservation, container, and holding time requirements for the analyses to be performed are identified in the Sample Authorization Form/Field Sampling Requirements. These items are maintained and verified by the Sample and Data Management Group.

\subsection{QUALITY CONTROL REQUIREMENTS}

The $\mathrm{QC}$ procedures must be followed in the field and laboratory to ensure that reliable data are obtained. When performing this field sampling effort, care shall be taken to prevent the crosscontamination of sampling equipment, sample bottles, and other equipment that could compromise sample integrity. Based on the volume of sample material that will be present at the site, no field QC samples will be collected. Disposal collection devices will be used whenever possible. Laboratory QC will be conducted on each batch process used. 
BHI-01022

Rev. 0

\subsection{INSTRUMENT CALIBRATION AND MAINTENANCE}

All field screening and analytical instruments shall be calibrated and maintained in accordance BHI-QA-03, Procedure 5.2. The results from all instrument calibration and maintenance activities shall be recorded in a bound logbook in accordance with procedures outlined in BHI-EE-01, Procedure 1.5, "Field Logbooks." Tags will be attached to all field screening and onsite analytical instruments noting the date when the instrument was last calibrated, along with the calibration expiration date.

\subsection{FIELD DOCUMENTATION}

Field documentation shall be kept in accordance with BHI-EE-01 including the following procedures, Procedure 1.5, and Procedure 3.0, "Chain of Custody."

\subsection{ASSESSMENTS AND RESPONSE ACTIONS}

The Compliance and Quality Programs Group may conduct random surveillance and assessments in accordance with BHI-MA-02, ERC Project Procedures, Procedure 5.3, "Self-Assessments," to verify compliance with the requirements outlined in this sampling and analysis instruction, project work packages, the Bechtel Hanford, Inc. (BHI) Quality Management Plan, and BHI procedures and regulatory requirements.

Deficiencies identified by one of these assessments shall be reported in accordance with BHI-MA-02, Procedure 5.3. Corrective actions will be taken by the Project Engineer in accordance with DOE/RL-96-68, Hanford Analytical Services Quality Assurance Requirements Documents, Volume 1, Section 4.0 (DOE 1996) to minimize recurrence.

\subsection{DATA VERIFICATION AND VALIDATION REQUIREMENTS}

Data verification and validation is performed on analytical data sets primarily to confirm that sampling and chain-of-custody documentation is complete, sample numbers can be tied to the specific sampling location, samples were analyzed within the required holding times, and analyses met the data quality requirements specified in the sampling and analysis instruction. All data verification and validation shall be performed in accordance with BHI-EE-01, Procedure 2.5, "Data Package Validation Process;" WHC-SD-EN-SP-001, Data Validation Procedure for Radiochemistry Analyses (WHC 1993a); and WHC-SD-EN-SP-002, Data Validation Procedure for Chemical Analyses (WHC 1993b). 
BHI-01022

Rev. 0

\subsection{MANAGEMENT OF INVESTIGATION DERIVED WASTE}

Investigation-derived waste generated by characterization activities will be managed in accordance with BHI-EE-10, Waste Management Plan. Unused samples and associated laboratory waste for the analysis will be disposition in accordance with the laboratory contract and agreements.

\subsection{HEALTH AND SAFETY}

All field operations will be performed in accordance with BHI health and safety requirements outlined in BHI-SH-01, Hanford ERC Environmental, Safety, and Health Program, and the requirements of HSRCM-1, Hanford Site Radiological Control Manual (DOE 1995). In addition, a work control package will be prepared in accordance with BHI-MA-02, which will further control site operations. This package will include a site-specific health and safety plan and applicable radiological work permits.

The sampling procedures and associated activities will take into consideration exposure reduction and contamination control techniques which will minimize the radiation exposure to the sampling team as required by BHI-QA-01, ERC Quality Program, and BHI-SH-01.

\subsection{REFERENCES}

BHI-EE-01, Environmental Investigations Procedures, Bechtel Hanford, Inc., Richland, Washington.

BHI-EE-10, Waste Management Plan, Bechtel Hanford, Inc., Richland, Washington.

BHI-HR-02, ERC Training Procedures, Bechtel Hanford, Inc., Richland, Washington.

BHI-MA-02, ERC Project Procedures, Bechtel Hanford, Inc., Richland, Washington.

BHI-QA-01, ERC Quality Program, Bechtel Hanford, Inc., Richland, Washington.

BHI-QA-03, ERC Quality Assurance, Bechtel Hanford, Inc., Richland, Washington.

BHI-SH-01, Hanford ERC Environmental, Safety, and Health Program, Bechtel Hanford, Inc., Richland, Washington. 
BHI-01022

Rev. 0

DOE, 1995, Hanford Site Radiological Control Manual, HSRCM-1, U.S. Department of Energy, Richland Operations Office, Richland, Washington.

DOE, 1996, Hanford Analytical Services Quality Assurance Requirements Documents, DOE/RL-96-68, Rev. 0, U.S. Department of Energy, Richland Operations Office, Richland, Washington.

WHC, 1993a, Data Validation Procedures for Radiological Analyses, WHC-SD-EN-SPP-001, Rev. 1, Westinghouse Hanford Company, Richland, Washington.

WHC, 1993b, Data Validation Procedures for Chemical Analyses, WHC-SD-EN-SPP-002, Rev. 2, Westinghouse Hanford Company, Richland, Washington. 
BHI-01022

Rev. 0

\section{DISTRIBUTION}

ONSITE (12 copies)

\section{$\underline{\text { ERC Team }}$}

T. M. Brown

S3-21

W. M. Hayward

T7-05

W. L. Osborne

T7-05

W. H. Price

$\mathrm{H} 0-20$

J. E Rugg

S3-21

P. J. Woods

S3-20

S/M\&T Project Files

S3-20

Document and Information Services (3)

H0-09

Hanford Technical Library

P8-55

DOE-RL Public Reading Room

$\mathrm{H} 2-53$ 